\title{
Long-Term Response to Sunitinib Treatment in Metastatic Renal Cell Carcinoma: A Pooled Analysis of Clinical Trials
}

\author{
Nizar M. Tannir, ${ }^{1}$ Robert A. Figlin, ${ }^{2}$ Martin E. Gore, ${ }^{3}$ M. Dror Michaelson, ${ }^{4}$ \\ Robert J. Motzer, ${ }^{5}$ Camillo Porta, ${ }^{6}$ Brian I. Rini, ${ }^{7}$ Caroline Hoang, ${ }^{8}$ Xun Lin, ${ }^{9}$ \\ Bernard Escudier ${ }^{10}$
}

\section{Abstract}

A subset of patients with metastatic renal cell carcinoma treated with sunitinib achieved long-term response (ie, progression-free survival [PFS] > 18 months). Long-term responders had improved objective response rate, PFS, and overall survival versus others. Patient baseline characteristics predictive of long-term response to sunitinib were identified.

Background: We characterized clinical outcomes of patients with metastatic renal cell carcinoma (mRCC) treated with sunitinib who were long-term responders (LTRs), defined as patients having progression-free survival (PFS) $>18$ months. Patients and Methods: A retrospective analysis of data from 5714 patients with mRCC treated with sunitinib in 8 phase II/III clinical trials and the expanded access program. Duration on-study and objective response rate (ORR) were compared between LTRs and patients with PFS $\leq 18$ months ("others"). PFS and overall survival (OS) were summarized using Kaplan-Meier methodology. Results: Overall, 898 (15.7\%) patients achieved a long-term response and $4816(84.3 \%)$ patients did not achieve long-term response. The median (range) duration on-study was 28.6 (16.870.7) months in LTRs and $5.5(0-68.8)$ months in others. ORR was $51 \%$ in LTRs versus $14 \%$ in others $(P<.0001)$. Median PFS in LTRs was 32.11 months and median OS was not reached. LTRs had higher percentage of early tumor shrinkage $\geq 10 \%$ at the first scan $(67.1 \%$ vs. $51.2 \% ; P=.0018)$ and greater median maximum on-study tumor shrinkage from baseline $(-56.9$ vs. $-27.1 ; P<.0001)$ versus others. White race, Eastern Cooperative Oncology Group performance status 0 , time from diagnosis to treatment $\geq 1$ year, clear cell histology, no liver metastasis, lactate dehydrogenase $\leq 1.5$ upper limit of normal (ULN), corrected calcium $\leq 10 \mathrm{mg} / \mathrm{dL}$, hemoglobin greater than the lower limit of normal, platelets less than or equal to ULN, body mass index $\geq 25 \mathrm{~kg} / \mathrm{m}^{2}$, and low neutrophil-to-lymphocyte ratio were associated with LTR. Conclusion: A subset of patients with $\mathrm{mRCC}$ treated with sunitinib achieved longterm response. LTRs had improved ORR, PFS, and OS.

Clinical Genitourinary Cancer, Vol. m, No. -., 1-7 @ 2017 Elsevier Inc. All rights reserved.

Keywords: Long-term response, Metastatic, Objective response rate, Predictors, Progression-free survival

\section{Introduction}

Sunitinib malate (Sutent), a multitargeted tyrosine kinase inhibitor, is approved globally for the treatment of metastatic renal cell

Trials registration numbers: NCT00054886, NCT00077974, NCT00083889, NCT00130897, NCT00089648, NCT00137423, NCT00267748, NCT00254540, NCT00338884.

${ }^{1}$ Division of Cancer Medicine, Department of Genitourinary Medical Oncology, The University of Texas M. D. Anderson Cancer Center, Houston, TX

${ }^{2}$ Samuel Oschin Comprehensive Cancer Institute, Cedars-Sinai Medical Center, Los Angeles, CA

${ }^{3}$ Royal Marsden Hospital NHS Trust, Fulham Road, London, UK

${ }^{4}$ Massachusetts General Hospital Cancer Center, Boston, MA

${ }^{5}$ Memorial Sloan Kettering Cancer Center, New York, NY

${ }^{6}$ Division of Medical Oncology, IRCCS San Matteo University Hospital Foundation, Pavia, Italy carcinoma (mRCC). ${ }^{1}$ Sunitinib has demonstrated efficacy in many clinical trials, ${ }^{2-6}$ and is a standard-of-care first-line treatment for patients with mRCC. ${ }^{7}$ In the pivotal trial, the median

${ }^{7}$ Cleveland Clinic Taussig Cancer Institute, Cleveland, $\mathrm{OH}$

${ }^{8}$ Pfizer Inc, New York, NY

${ }^{9}$ Pfizer Oncology, La Jolla, CA

${ }^{10}$ Gustave Roussy, Villejuif Cedex, France

Submitted: Apr 25, 2017; Revised: Jun 5, 2017; Accepted: Jun 13, 2017

Address for correspondence: Nizar M. Tannir, MD, Division of Cancer Medicine,

Department of Genitourinary Medical Oncology, The University of Texas M. D.

Anderson Cancer Center, 1155 Pressler Street, Houston, TX 77030

E-mail contact: ntannir@mdanderson.org 


\section{Long-term Response to Sunitinib Treatment}

progression-free survival (PFS) was significantly longer in patients with mRCC treated with sunitinib versus interferon-alfa (11 vs. 5 months, respectively). ${ }^{3}$ Efficacy of sunitinib was confirmed by almost all subsequent trials performed in the first-line setting. ${ }^{2,8-12}$ Median PFS with sunitinib in the first-line setting ranged between 9 and 11 months. ${ }^{2,8,10-12}$ Median PFS with other targeted therapies in the first-line setting ranged between 8 and 11 months, ${ }^{4,13,14}$ and in the second-line setting ranged between 4 and 8 months. ${ }^{15-18}$

Molina et $\mathrm{al}^{19}$ reported a subset of patients $(\mathrm{n}=34)$ with mRCC treated in clinical trials at Memorial Sloan Kettering Cancer Center (MSKCC) who achieved a long-term response with sunitinib, defined as patients achieving durable complete response or remaining progression-free for $>18$ months. Of this group, 3 patients achieved complete response and 24 achieved partial response at 18 months after treatment start; the median PFS at a landmark time point of 18 months after treatment initiation was 17.4 months (95\% confidence interval [CI], 7.0-29.9 months). ${ }^{19}$ Lack of bone or lung metastases and favorable MSKCC risk status were found to be associated with long-term response. ${ }^{19}$

The goal of this retrospective study was to identify and characterize sunitinib long-term responders (LTRs), defined as patients with mRCC having PFS $>18$ months while on sunitinib therapy. We used a large, contemporary clinical trial database of patients with mRCC who were treated with sunitinib to describe the clinical characteristics, duration of treatment, and clinical outcome of patients identified as LTRs, and to identify risk factors that may predict long-term response.

\section{Methods}

\section{Patients and Study Design}

A retrospective analysis of data in patients $(\mathrm{n}=5714)$ with $\mathrm{mRCC}$ treated with sunitinib in 8 phase II or III clinical trials $(\mathrm{n}=1173)$ and patients $(n=4543)$ treated in the expanded access program (EAP; Supplemental Table 1 in the online version). In 6 trials $(\mathrm{n}=$ 5199), sunitinib was started at $50 \mathrm{mg}$ daily for 4 weeks followed by a 2-week break (" $4 / 2$ schedule") $3,5,6,10,11,20-22$; in 2 trials $(\mathrm{n}=226$ ), the starting dose was $37.5 \mathrm{mg}$ administered on a continuous oncedaily dosing (CDD) regimen ${ }^{8,23}$; and, in 1 trial $(n=289)$, the starting dose was $50 \mathrm{mg} 4 / 2$ schedule or $37.5 \mathrm{mg}$ CDD.

Phase II or III trials included patients with histologically confirmed clear cell RCC with measurable disease, metastases (except for 1 study by Motzer et al, ${ }^{9}$ wherein patients could have locally recurrent or mRCC), adequate organ function, and Eastern Cooperative Oncology Group performance status (ECOG PS) 0 or 1 or Karnofsky performance score $>70 . .^{3,5,6,8,9,20,22,23}$ In the EAP trial, patients had histologically confirmed mRCC (of all histological subtypes) with adequate organ function. ${ }^{10,11}$ In all trials, tumor response was assessed according to Response Evaluation Criteria in Solid Tumors criteria. A central independent review of response was conducted in 3 trials. ${ }^{3,6,22}$ All trials were registered on ClinicalTrials.gov and were previously reported (Supplemental Table 1 in the online version).

\section{Statistical Analysis}

Dose reduction/interruptions, treatment discontinuation, and treatment-related adverse events (AEs) were summarized between LTRs and patients who had PFS $\leq 18$ months ("others").
Multiple univariable logistic regression analyses were conducted to identify potential baseline characteristics associated with LTRs. Baseline characteristics assessed included age, race, sex, ECOG PS, time from diagnosis, histology, metastasis, serum lactate dehydrogenase (LDH), corrected serum calcium, hemoglobin, platelets, prior nephrectomy, prior therapy, body mass index (BMI), and neutrophil-to-lymphocyte ratio (NLR). A multivariable logistic regression analysis was further conducted for the baseline characteristics that were statistically significant $(P<.05)$ in the univariable analyses to identify the independent baseline factors associated with LTRs.

A Cox proportional analysis was conducted to identify baseline and post-baseline characteristics associated with overall survival (OS).

Tumor burden was determined based on the sum of the longest diameters of the target lesions by the investigators. Median tumor burden at baseline was compared between LTRs and others. Early tumor shrinkage, defined as $\geq 10 \%$ reduction in sum of the longest diameters of target lesions at the first scan after initiation of sunitinib treatment, was calculated and compared between LTRs and others. The $10 \%$ threshold was selected based on a study showing that early tumor shrinkage $\geq 10 \%$ at first post-baseline assessment could serve as a putative early end point in patients with mRCC. ${ }^{24}$ Patients from the EAP were excluded from the analysis of tumor burden and tumor shrinkage because tumor response assessments were not mandated and were performed at the discretion of the investigators. Because early decline in NLR is associated with favorable outcome and early increase in NLR with worse outcome, ${ }^{25}$ these trends were compared separately.

\section{Results \\ Patients}

A total of $898(15.7 \%)$ patients met the definition of LTRs. The remaining $4816(84.3 \%)$ had PFS $<18$ months that included stable disease, progressive disease, or death (ie, others). Patient demographics were similar between the LTRs and others (Supplemental Table 2 in the online version). Patient disease characteristics were mostly similar between the 2 groups, except for ECOG PS 0, time from diagnosis to treatment $\geq 1$ year, and low MSKCC risk group that were more common in the LTR versus others. LTRs also had favorable laboratory findings versus others (Supplemental Table 2 in the online version).

\section{Sunitinib Treatment and AEs}

Overall, $14.9 \%$ of LTRs and $14.0 \%$ of others received sunitinib as first-line therapy, whereas $85.1 \%$ of LTRs and $86.0 \%$ of others received sunitinib as second-line therapy. Most patients (865 [96.3\%] of LTRs and 4406 [91.5\%] of others) received sunitinib on a $4 / 2$ schedule; $33(3.7 \%)$ of LTRs and $410(8.5 \%)$ of others received sunitinib on CDD. The median (range) duration on-study was 28.6 (16.8-70.7) months in LTRs and 5.5 (0-68.8) months in others.

A similar number of patients discontinued treatment due to insufficient clinical response in the 2 groups $(34.9 \%$ in LTRs and $36.1 \%$ in others). Dose reduction/interruption occurred in $58.5 \%$ of LTRs and $31.5 \%$ of others and discontinuation of treatment due to AEs occurred in $11.1 \%$ of LTRs and $16.5 \%$ of others (see 


\begin{tabular}{|c|c|c|c|}
\hline & $\begin{array}{c}\text { LTRs } \\
n=898\end{array}$ & $\begin{array}{c}\text { Others } \\
\mathrm{n}=\mathbf{4 8 1 6}\end{array}$ & $\begin{array}{c}\text { All Patients } \\
\mathrm{n}=\mathbf{5 7 1 4}\end{array}$ \\
\hline \multicolumn{4}{|l|}{ Dose Reductions/interruptions } \\
\hline Yes & 525 (58.5) & 1518 (31.5) & 2043 (35.8) \\
\hline \multicolumn{4}{|l|}{ Reason for discontinuation } \\
\hline Adverse event & $100(11.1)$ & 794 (16.5) & $894(15.6)$ \\
\hline Completed & $144(16.0)$ & $249(5.2)$ & $393(6.9)$ \\
\hline $\begin{array}{l}\text { Global deterioration of } \\
\text { health status }\end{array}$ & 0 & $16(0.3)$ & $16(0.3)$ \\
\hline Insufficient clinical response & $313(34.9)$ & 1739 (36.1) & 2052 (35.9) \\
\hline Insufficient response & $13(1.4)$ & $63(1.3)$ & $76(1.3)$ \\
\hline Lost to follow-up & $20(2.2)$ & $118(2.5)$ & $138(2.4)$ \\
\hline $\begin{array}{l}\text { Objective progression or } \\
\text { relapse }\end{array}$ & $10(1.1)$ & $197(4.1)$ & 207 (3.6) \\
\hline Other & $82(9.1)$ & $364(7.6)$ & $446(7.8)$ \\
\hline Protocol violation & $4(0.4)$ & $16(0.3)$ & $20(0.4)$ \\
\hline Study terminated by sponsor & $102(11.4)$ & $24(0.5)$ & $126(2.2)$ \\
\hline Died & $48(5.3)$ & $879(18.3)$ & $927(16.2)$ \\
\hline $\begin{array}{l}\text { No longer willing to } \\
\text { participate in study }\end{array}$ & $51(5.7)$ & $319(6.6)$ & $370(6.5)$ \\
\hline $\begin{array}{l}\text { Refused continued treatment } \\
\text { for reason other than adverse } \\
\text { event }\end{array}$ & $1(0.1)$ & $13(0.3)$ & $14(0.2)$ \\
\hline Withdrew consent & $9(1.0)$ & $20(0.4)$ & $29(0.5)$ \\
\hline Other & 0 & $1(0.0)$ & $1(0.0)$ \\
\hline Missing & $1(0.1)$ & $4(0.1)$ & $5(0.1)$ \\
\hline
\end{tabular}

NOTE. Values are $\mathrm{n}(\%)$.

Abbreviation: LTR = long-term responder

summary in Table 1). The most common grade $\geq 3$ treatmentrelated AEs reported by LTRs were hypertension (12.8\%), palmar-plantar erythrodysesthesia $(12.5 \%)$, diarrhea and neutropenia (10.2\% each), and fatigue (10.1\%; Table 2$)$.

\section{Efficacy}

Based on univariable logistic regression analyses of baseline characteristics, white race, ECOG PS 0, or 1-2 (vs. ECOG $>2$ ), time from diagnosis to treatment $\geq 1$ year, clear cell histology, no liver or bone metastasis, serum $\mathrm{LDH} \leq 1.5$ upper limit of normal $(\mathrm{ULN})$, corrected serum calcium $\leq 10 \mathrm{mg} / \mathrm{dL}$, hemoglobin greater than lower limit of normal (LLN), platelets less than or equal to ULN, BMI $\geq 25 \mathrm{~kg} / \mathrm{m}^{2}$, prior nephrectomy, and low $(\leq 3)$ NLR were associated with longer PFS (Table 3).

Using a multivariable logistic regression analysis, white race, ECOG PS 0 , time from diagnosis to treatment $\geq 1$ year, clear cell histology, no liver metastasis, serum LDH $\leq 1.5$ ULN, corrected serum calcium $\leq 10 \mathrm{mg} / \mathrm{dL}$, hemoglobin greater than LLN, platelets less than or equal to ULN, BMI $\geq 25 \mathrm{~kg} / \mathrm{m}^{2}$, and low $(\leq 3)$ NLR were associated with longer PFS (Table 4).

A Cox proportional analysis of OS demonstrated that age $<65$ years, ECOG PS 0, time from diagnosis to treatment $\geq 1$ year, lack of metastasis (lung, liver, bone, or other site), hemoglobin greater than LLN, platelets less than or equal to ULN, and NLR $\leq 3$ were associated with longer OS (Supplemental Table 3 in the online version).

Objective response rate (ORR; complete or partial response) was $51.0 \%$ in LTRs versus $14.0 \%$ in others $(P<.0001$; Table 5$)$. For LTRs, median PFS (95\% CI) was 32.11 (30.30-33.76) months and median OS was not reached (Figure 1). For others, median PFS $(95 \% \mathrm{CI})$ was $7.16(6.86-7.62)$ months and median OS was 14.74 months.

Of the 1171 patients included in the tumor shrinkage analysis, 167 were LTRs and 1007 were others. Median tumor burden at baseline differed significantly between LTRs and others (85.0 vs. 100.5 , respectively; $P=.0041$ ). Median tumor shrinkage at the first post-baseline scan also differed significantly between LTRs and others (change from baseline, -17.1 vs. -11.5 , respectively; $P<.0001)$. More patients in the LTR group had early tumor shrinkage $\geq 10 \%$ at the first scan versus others $(67.1 \%$ vs. $51.2 \%$, respectively; $P=.0018)$. The median maximum on-study tumor shrinkage from baseline was -56.9 for LTRs versus -27.1 for others $(P<.0001)$

More LTRs (63.9\%) had low NLR at baseline versus others (46.7\%; Supplemental Table 4 in the online version). In both groups, there were significant differences in OS, PFS, and ORR in patients who had low $(\leq 3)$ NLR both at baseline and after 6 weeks versus patients with low NLR at baseline and high ( $>3$ ) NLR (Supplemental Table 4 in the online version). NLR change from high at baseline to low at 6 weeks was also associated with better outcome versus NLR high at baseline and high after 6 weeks, although the differences were not statistically significant (Supplemental Table 4 in the online version).

\section{LTRs Over Time}

Among the 898 LTR patients who achieved PFS > 18 months, 532 (59.2\%) achieved PFS $>2$ years, $226(25.2 \%)$ achieved PFS $>3$ years, $98(10.9 \%)$ achieved PFS $>4$ years, and $35(3.9 \%)$ achieved PFS $>5$ years (Figure 2). The number of patients censored in the others group (ie, PFS $<18$ months) over time (using the 2-, 3-, 4-, and 5-year cutoffs) is also reported (Figure 2).

\section{Discussion}

In this analysis, we identified a subset of patients with mRCC who were LTRs, defined as patients who had PFS $>18$ months while on sunitinib therapy. Not surprisingly, LTRs had improved PFS and OS (median PFS, 32.11 months; median OS, not reached). Furthermore, objective response was achieved in $51.0 \%$ of LTRs compared with $19.8 \%$ in the overall population in this study and the $38.0 \%$ of patients reported previously for sunitinib-treated patients. $^{26}$

LTRs remained on-study longer than others (median duration on-study, 28.6 vs. 5.5 months, respectively). As expected of patients treated for a longer duration, LTRs experienced more treatmentrelated AEs versus others. However, the safety profile of sunitinib in LTRs was similar to previous reports of short- and long-term safety of sunitinib treatment in patients with mRCC. ${ }^{2,3,10,27}$ Previous studies have shown that hypertension and neutropenia were associated with improved clinical outcome in patients treated with sunitinib. $^{28,29}$ Indeed, hypertension and neutropenia in our analysis were found to be higher among LTRs versus others $(43.8 \%$ vs. 


\section{Long-term Response to Sunitinib Treatment}

Table 2 Treatment-Related Adverse Events 0ccurring in $>\mathbf{2 0} \%$ of Patients in Any Group

\begin{tabular}{|c|c|c|c|c|c|c|}
\hline \multirow{2}{*}{$\begin{array}{l}\text { MedDRA } \\
\text { Preferred Term }\end{array}$} & \multicolumn{2}{|c|}{$\begin{array}{c}\text { LTRs } \\
\mathrm{n}=898\end{array}$} & \multicolumn{2}{|c|}{$\begin{array}{c}\text { Others } \\
\mathrm{n}=\mathbf{4 8 1 6}\end{array}$} & \multicolumn{2}{|c|}{$\begin{array}{c}\text { All Patients } \\
\mathrm{n}=5714\end{array}$} \\
\hline & All Grades & Grade $\geq 3$ & All Grades & Grade $\geq 3$ & All Grades & Grade $\geq 3$ \\
\hline Diarrhea & $683(76.1)$ & $92(10.2)$ & $2161(44.9)$ & $238(4.9)$ & $2844(49.8)$ & $330(5.8)$ \\
\hline Fatigue & $519(57.8)$ & $91(10.1)$ & $1972(41.0)$ & $446(9.3)$ & $2491(43.6)$ & $537(9.4)$ \\
\hline Nausea & $413(46.0)$ & $26(2.9)$ & $1804(37.5)$ & $127(2.6)$ & 2217 (38.8) & $153(2.7)$ \\
\hline Decreased appetite & $344(38.3)$ & $12(1.3)$ & $1448(30.1)$ & $113(2.4)$ & 1792 (31.4) & $125(2.2)$ \\
\hline Stomatitis & $328(36.5)$ & $32(3.6)$ & $1320(27.4)$ & $130(2.7)$ & $1648(28.8)$ & $162(2.8)$ \\
\hline Mucosal inflammation & 337 (37.5) & $30(3.3)$ & $1296(26.9)$ & $132(2.7)$ & $1633(28.6)$ & $162(2.8)$ \\
\hline Dysgeusia & $340(37.9)$ & $3(0.3)$ & $1291(26.8)$ & $27(0.6)$ & $1631(28.5)$ & $30(0.5)$ \\
\hline PPE & $454(50.6)$ & $112(12.5)$ & $1163(24.2)$ & $317(6.6)$ & $1617(28.3)$ & $429(7.5)$ \\
\hline Vomiting & $259(28.8)$ & $23(2.6)$ & $1354(28.1)$ & $154(3.2)$ & $1613(28.2)$ & $177(3.1)$ \\
\hline Hypertension & $393(43.8)$ & $115(12.8)$ & $1072(22.3)$ & $266(5.5)$ & $1465(25.6)$ & $381(6.7)$ \\
\hline Thrombocytopenia & 253 (28.2) & $64(7.1)$ & $973(20.2)$ & $395(8.2)$ & $1226(21.5)$ & $459(8.0)$ \\
\hline Asthenia & $222(24.7)$ & $54(6.0)$ & $979(20.3)$ & $307(6.4)$ & $1201(21.0)$ & $361(6.3)$ \\
\hline Dyspepsia & 317 (35.3) & $12(1.3)$ & 881 (18.3) & $18(0.4)$ & $1198(21.0)$ & $30(0.5)$ \\
\hline Rash & 266 (29.6) & $15(1.7)$ & 801 (16.6) & $35(0.7)$ & 1067 (18.7) & $50(0.9)$ \\
\hline Anemia & 197 (21.9) & $45(5.0)$ & 760 (15.8) & $206(4.3)$ & 957 (16.8) & $251(4.4)$ \\
\hline Neutropenia & $232(25.8)$ & $92(10.2)$ & 667 (13.9) & $283(5.9)$ & $899(15.7)$ & $375(6.6)$ \\
\hline Epistaxis & $198(22.1)$ & $6(0.7)$ & 634 (13.2) & $33(0.7)$ & 832 (14.6) & $39(0.7)$ \\
\hline Hypothyroidism & 321 (35.8) & $17(1.9)$ & $362(7.5)$ & $21(0.4)$ & $683(12.0)$ & $38(0.7)$ \\
\hline Pain in extremity & $218(24.3)$ & $16(1.8)$ & 416 (8.6) & $43(0.9)$ & 634 (11.1) & $59(1.0)$ \\
\hline
\end{tabular}

NOTE. Values are $n(\%)$.

Abbreviations: LTR = long-term responder; MedDRA = Medical Dictionary for Regulatory Activities coding dictionary; PPE = palmar-plantar erythrodysesthesia syndrome.

$22.3 \%$, and $25.8 \%$ vs. $13.9 \%$, respectively). ${ }^{28,29}$ Furthermore, LTRs had a numerically higher rate of dose reductions/interruptions and a numerically lower rate of treatment discontinuations due to AEs versus others; this higher incidence of AEs is in line with the known relation between toxicity and efficacy. The lower rate of treatment discontinuation in LTRs might be due to better AE management in patients who had better efficacy, and better baseline ECOG PS in the LTRs group.

Retrospective analyses showed early tumor shrinkage $\geq 10 \%$ at first scan after baseline may have predictive and prognostic value for PFS and OS in patients with mRCC. ${ }^{24,30,31}$ In our analysis, although early tumor shrinkage $\geq 10 \%$ was significantly more common in LTRs (67\%) versus others (51\%), it occurred in most patients in both groups. A study by Grünwald and colleagues ${ }^{32}$ showed that the magnitude of tumor shrinkage correlated with a better survival rate in patients with mRCC. The current analysis found the median maximum on-study tumor shrinkage was significantly greater in LTRs versus others, potentially contributing to improved PFS and OS in LTRs.

An elevated baseline NLR has been shown to be associated with a poor prognosis in patients with mRCC. ${ }^{33,34}$ Our results showed that a decrease in NLR from baseline to week 6 was associated with better ORR, PFS, and OS, whereas an increase in NLR was associated with worse outcome. These findings are consistent with a previous study that showed early decline of NLR in response to targeted therapy was associated with favorable outcomes, and an increase in NLR was associated with the opposite effect. ${ }^{25}$

In the current study, risk factors associated with long-term response included white race, ECOG PS 0, time from diagnosis to treatment $\geq 1$ year, clear cell histology, no liver metastasis, serum $\mathrm{LDH} \leq 1.5 \mathrm{ULN}$, corrected serum calcium $\leq 10 \mathrm{mg} / \mathrm{dL}$, BMI $\geq 25 \mathrm{~kg} / \mathrm{m}^{2}$, and favorable hematology values. These baseline characteristics associated with long-term response are consistent with previously reported predictors for survival in patients with mRCC treated with sunitinib ${ }^{2,26,35}$ and with other inhibitors of the vascular endothelial growth factor pathway. ${ }^{36}$ Four of the risk factors identified in this study (ie, hemoglobin $<1.5$ ULN, corrected calcium, LDH > 1.5 ULN, and time from initial RCC diagnosis) constitute the 5-factor MSKCC model that is the most commonly used prognostic model. ${ }^{37}$ Because of the variations in patient characteristics, identifying early predictors of LTRs may help guide the treatment selection for particular patients with specific baseline characteristics. Tailoring treatment to the patient characteristics may improve outcome in patients with mRCC.

Although this study is based on a large, contemporary clinical trial database of patients with mRCC treated with sunitinib, it has limitations. In addition to the inherent issues associated with a retrospective analysis, the patient population was heterogeneous and included treatment-naïve patients, as well as previously treated patients who received different dosing regimens. Most patients were excluded from the tumor shrinkage analysis because tumor assessment was not mandated in the EAP study. Another potential limitation of this study is the selection of the 18-month cutoff to define LTRs. However, a cut point of 18 months is $64 \%$ longer than the median PFS observed in the sunitinib pivotal study, and is longer than the median PFS observed in the first-line setting with other targeted therapies (range, 64\%-125\%). ${ }^{12-14}$ Finally, $>85 \%$ of patients in this study received sunitinib as second-line therapy, before 
Table 3 Univariable Logistic Regression of Baseline Characteristics Predictive of LTRs Versus Others

\begin{tabular}{|c|c|c|c|}
\hline Parameter & Odds Ratio & $95 \% \mathrm{Cl}$ & $\boldsymbol{P}$ \\
\hline Age, y (<65 vs. $\geq 65)$ & 1.014 & $0.871-1.180$ & .8602 \\
\hline Sex (female vs. male) & 0.895 & $0.760-1.054$ & .1853 \\
\hline \multicolumn{4}{|l|}{ Race } \\
\hline Asian vs. white & 0.753 & $0.568-0.998$ & .0481 \\
\hline Black vs. white & 0.315 & $0.098-1.013$ & .0526 \\
\hline Not applicable vs. white & 0.414 & $0.191-0.897$ & .0255 \\
\hline Other vs. white & 0.971 & $0.751-1.253$ & .8186 \\
\hline \multicolumn{4}{|l|}{ ECOG PS } \\
\hline 0 vs. $1-2$ & 2.078 & $1.793-2.409$ & $<.0001$ \\
\hline$>2$ vs. $1-2$ & 0.277 & $0.087-0.881$ & .0297 \\
\hline $\begin{array}{l}\text { Time from diagnosis to } \\
\text { treatment ( } \geq 1 \text { vs. }<1 \text { y) }\end{array}$ & 1.709 & $1.458-2.003$ & $<.0001$ \\
\hline \multicolumn{4}{|l|}{ Histology } \\
\hline $\begin{array}{l}\text { Non-clear cell histology vs. } \\
\text { clear cell }\end{array}$ & 0.677 & $0.524-0.875$ & .0029 \\
\hline Not reported vs. clear cell & $<0.001$ & $\begin{array}{c}<0.001- \\
>999.999\end{array}$ & .9519 \\
\hline \multicolumn{4}{|l|}{ Metastasis (no vs. yes) } \\
\hline Liver & 1.458 & $1.226-1.735$ & $<.0001$ \\
\hline Lung & 1.171 & $0.991-1.384$ & .0631 \\
\hline Bone & 1.466 & $1.248-1.722$ & $<.0001$ \\
\hline Other site & 1.073 & $0.927-1.241$ & .3471 \\
\hline LDH (>1.5 vs. $\leq 1.5$ ULN) & 0.401 & $0.296-0.544$ & $<.0001$ \\
\hline $\begin{array}{l}\text { Corrected calcium (>10 } \\
\text { vs. } \leq 10 \mathrm{mg} / \mathrm{dL} \text { ) }\end{array}$ & 0.414 & $0.330-0.520$ & $<.0001$ \\
\hline Hemoglobin (>LLN vs. $\leq$ LLN) & 2.375 & $2.050-2.753$ & $<.0001$ \\
\hline Platelets ( $\leq$ ULN vs. $>$ ULN) & 2.975 & $2.329-3.802$ & $<.0001$ \\
\hline Prior nephrectomy (no vs. yes) & 0.567 & $0.433-0.742$ & $<.0001$ \\
\hline Prior therapy (no vs. yes) & 1.030 & $0.875-1.213$ & .7193 \\
\hline BMI ( $<25$ vs. $\geq 25 \mathrm{~kg} / \mathrm{m}^{2}$ ) & 0.565 & $0.482-0.662$ & $<.0001$ \\
\hline NLR (low $[\leq 3]$ vs. high $[>3]$ ) & 2.366 & $2.037-2.748$ & $<.0001$ \\
\hline $\begin{array}{l}\text { Baseline tumor burden } \\
\text { (<median vs. } \geq \text { median) }\end{array}$ & 0.990 & $0.711-1.379$ & .9517 \\
\hline
\end{tabular}

Abbreviations: $\mathrm{BMI}=$ body mass index; $\mathrm{Cl}=$ confidence interval; ECOG PS = Eastern Cooperative Oncology Group performance status; $L D H=$ lactate dehydrogenase; LLN = lowe limit of normal; LTR = long-term responder; NLR = neutrophil-to-lymphocyte ratio; $\mathrm{PFS}=$ progression-free survival; ULN = upper limit of normal.

sunitinib becoming the standard of care in many countries, so it is likely that patients with poorer prognosis at diagnosis were not able to survive long enough to receive sunitinib. Therefore, the results from this study are probably different from what might now be expected with sunitinib.

\section{Conclusions}

A subset of patients with mRCC treated with sunitinib in multiple clinical trials were LTRs; $15.7 \%$ achieved PFS > 18 months, and $3.9 \%$ achieved PFS $>5$ years. Long-term treatment with sunitinib was associated with a numerically higher rate of dose reductions/interruptions but a numerically lower rate of treatment discontinuations due to AEs. LTRs had improved ORR, PFS, and OS. Moreover, LTRs had a higher percentage of early tumor
Table 4 Multivariable Logistic Regression Comparison of Baseline Characteristics Predictive of LTRs Versus Others

\begin{tabular}{|c|c|c|c|}
\hline Parameter & Odds Ratio & $95 \% \mathrm{CI}$ & $\boldsymbol{P}$ \\
\hline \multicolumn{4}{|l|}{ Race } \\
\hline Asian vs. white & 0.711 & $0.515-0.981$ & .0380 \\
\hline Black vs. white & 0.584 & $0.172-1.985$ & .3891 \\
\hline Not applicable vs. white & 0.107 & $0.026-0.443$ & .0020 \\
\hline Other vs. white & 0.980 & $0.716-1.341$ & .8977 \\
\hline \multicolumn{4}{|l|}{ ECOG PS } \\
\hline 0 vs. $1-2$ & 1.583 & $1.317-1.902$ & $<.0001$ \\
\hline$>2$ vs. $1-2$ & 0.393 & $0.094-1.643$ & .2009 \\
\hline $\begin{array}{l}\text { Time from diagnosis to } \\
\text { treatment ( } \geq 1 \text { vs. }<1 \text { y) }\end{array}$ & 1.337 & $1.097-1.629$ & .0040 \\
\hline \multicolumn{4}{|l|}{ Histology } \\
\hline $\begin{array}{l}\text { Non-clear cell histology vs. } \\
\text { clear cell }\end{array}$ & 0.666 & $0.483-0.918$ & .0132 \\
\hline Not reported vs. clear cell & $<0.001$ & $\begin{array}{c}<0.001- \\
>999.999\end{array}$ & .9819 \\
\hline \multicolumn{4}{|l|}{ Metastasis (no vs. yes) } \\
\hline Liver & 1.240 & $1.003-1.531$ & .0463 \\
\hline Bone & 1.132 & $0.926-1.384$ & .2252 \\
\hline LDH (>1.5 vs. $\leq 1.5$ ULN) & 0.663 & $0.475-0.926$ & .0158 \\
\hline $\begin{array}{l}\text { Corrected calcium (>10 } \\
\text { vs. } \leq 10 \mathrm{mg} / \mathrm{dL} \text { ) }\end{array}$ & 0.572 & $0.438-0.748$ & $<.0001$ \\
\hline Hemoglobin (>LLN vs. $\leq$ LLN) & 1.353 & $1.121-1.633$ & .0016 \\
\hline Platelets ( $\leq$ ULN vs. $>$ ULN) & 1.793 & $1.325-2.425$ & .0002 \\
\hline Prior nephrectomy (no vs. yes) & 0.889 & $0.631-1.253$ & .5017 \\
\hline BMI (<25 vs. $\left.\geq 25 \mathrm{~kg} / \mathrm{m}^{2}\right)$ & 0.801 & $0.662-0.969$ & .0226 \\
\hline NLR (low [ $\leq 3]$ vs. high [ $>3]$ ) & 1.514 & $1.262-1.816$ & $<.0001$ \\
\hline
\end{tabular}

Abbreviations: $\mathrm{BMI}=$ body mass index; $\mathrm{Cl}=$ confidence interval; $\mathrm{ECOG} P \mathrm{PS}=$ Eastern Cooperative Oncology Group performance status; $L D H=$ lactate dehydrogenase; $L L N=$ lower limit of normal; LTR = long-term responder; NLR = neutrophil-to-lymphocyte ratio; PFS = progression-free survival; ULN = upper limit of normal.

shrinkage $\geq 10 \%$ at the first scan and greater median maximum onstudy tumor shrinkage from baseline versus others. Patient baseline characteristics predicting for LTR include white race, ECOG PS 0, time from diagnosis to treatment $\geq 1$ year, clear cell histology, no liver metastasis, serum LDH $\leq 1.5 \mathrm{ULN}$, corrected serum calcium $\leq 10 \mathrm{mg} / \mathrm{dL}$, hemoglobin greater than LLN, platelets less than or equal to ULN, BMI $\geq 25 \mathrm{~kg} / \mathrm{m}^{2}$, and low $(\leq 3)$ NLR.

Table 5 Best Observed Objective Response

\begin{tabular}{l|c|c|c} 
& LTRs & Others & All Patients \\
Complete response & $55(6.1)$ & $23(0.5)$ & $78(1.4)$ \\
Partial response & $403(44.9)$ & $652(13.5)$ & $1055(18.5)$ \\
Stable disease & $437(48.7)$ & $2422(50.3)$ & $2859(50.0)$ \\
\hline Progressive disease $^{2}$ & $3(0.3)$ & $710(14.7)$ & $713(12.5)$ \\
Other $^{\mathrm{n}}$ & 0 & $1009(21.0)$ & $1009(17.7)$ \\
ORR & $458(51.0)$ & $675(14.0)$ & $1133(19.8)$ \\
\hline
\end{tabular}

NOTE. Values are $\mathrm{n}(\%)$.

Abbreviations: LTR $=$ long-term responder; ORR $=$ objective response rate.

ancludes early death, indeterminate, no post-baseline tumor assessment, not assessed, not evaluable, symptomatic deterioration, and missing response. 


\section{Long-term Response to Sunitinib Treatment}

Figure 1 Kaplan-Meier Estimates of Overall Survival in LTRs

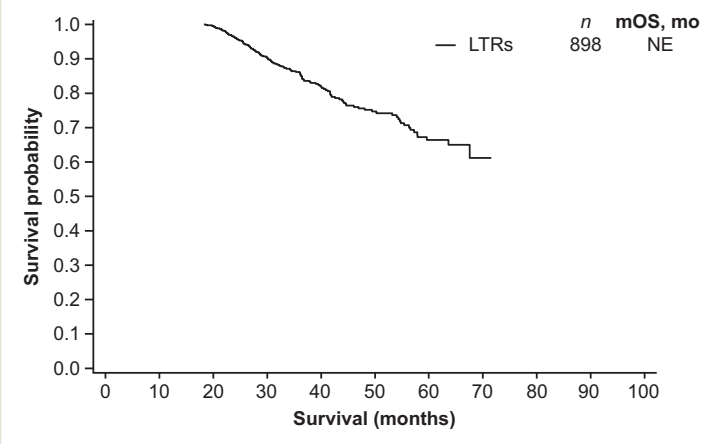

Abbreviations: $\mathrm{LTR}=$ long-term responder; $\mathrm{mOS}=$ median overall survival; $\mathrm{NE}=$ not estimable.

\section{Clinical Practice Points}

- Sunitinib, a multitargeted tyrosine kinase inhibitor, has demonstrated efficacy in many clinical trials, and is a standard-ofcare first-line treatment for patients with mRCC.

- Of the 5714 patients with mRCC treated with sunitinib in 8 phase II/III clinical trials and in the EAP, 898 (15.7\%) patients achieved a long-term response, defined as patients having PFS $>18$ months while on sunitinib therapy.

- LTRs had improved ORR, PFS, and OS. The median maximum on-study tumor shrinkage was significantly greater in LTRs versus others, potentially contributing to improved PFS and OS in LTRs.

- The safety profile of sunitinib in LTRs was similar to previous reports of short- and long-term safety of sunitinib treatment in patients with mRCC.

- White race, ECOG PS 0 , time from diagnosis to treatment $\geq 1$ year, clear cell histology, no liver metastasis, serum $\mathrm{LDH} \leq 1.5$ ULN, corrected serum calcium $\leq 10 \mathrm{mg} / \mathrm{dL}$, hemoglobin

\section{Figure 2 LTRs and Others Over Time}

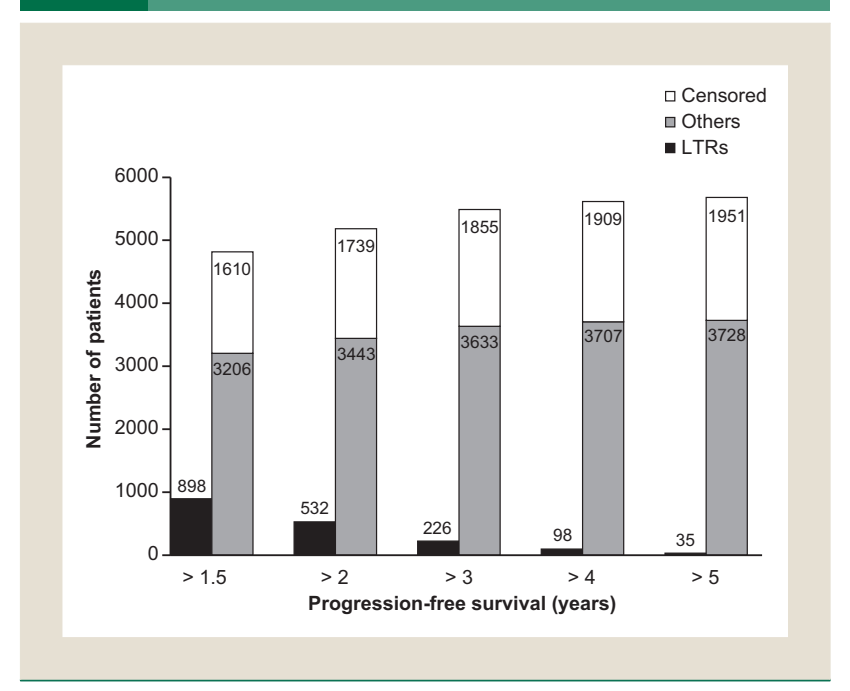

Abbreviation: LTR = long-term responder. greater than LLN, platelets less than or equal to ULN, BMI $\geq 25 \mathrm{~kg} / \mathrm{m}^{2}$, and low $(\leq 3)$ NLR were associated with long-term response.

\section{Acknowledgments}

This study was sponsored by Pfizer. Medical writing support was provided by Vardit Dror, PhD, of Engage Scientific Solutions and was funded by Pfizer Inc.

\section{Disclosure}

N.M. Tannir reports research funding and consultation fees from Pfizer, Novartis, and Exelixis and research funding from BMS. R.A. Figlin reports research funding from Argos, Bristol-Myers Squibb, GlaxoSmithKline, and Immatics and research funding and consultation fees from Novartis and Pfizer. M.D. Michaelson reports research funding and consultation fees from Pfizer, Novartis, and Eisai; consultation fees from Medivation and Astellas; and research funding from Millennium, Argos, and Tracon. R.J. Motzer reports research funding and consultation fees from Pfizer, Novartis, and Eisai and research funding from BMS, Exelixis, and GlaxoSmithKline. C. Porta reports research funding from Pfizer and consultation fees from Pfizer, Novartis, BMS, Roche-Genentech, Exelixis, Peloton, and EUSA Pharma. B.I. Rini reports research funding and consultation fees from Pfizer, GlaxoSmithKline, and Merck and research funding from BMS, Genentech, and Acceleron. B. Escudier received an honorarium from Pfizer, Novartis, GlaxoSmithKline, Bayer, and Exelixis. M.E. Gore has declared no conflict of interest, but acknowledges NHS funding from the NIHR Biomedical Research Centre at the Royal Marsden Hospital and Institute of Cancer Research. C. Hoang and X. Lin are full-time employees of Pfizer.

\section{Supplemental Data}

Supplemental tables accompanying this article can be found in the online version at http://dx.doi.org/10.1016/j.clgc.2017.06.005.

\section{References}

1. SUTENT® (sunitinib malate) [package insert], New York, NY: Pfizer Inc Available at:http://labeling.pfizer.com/ShowLabeling.aspx?id=607. Accessed: January 6, 2016.

2. Motzer RJ, Hutson TE, Tomczak P, et al. Overall survival and updated results for sunitinib compared with interferon alfa in patients with metastatic renal cell carcinoma. J Clin Oncol 2009; 27:3584-90.

3. Motzer RJ, Hutson TE, Tomczak P, et al. Sunitinib versus interferon alfa in metastatic renal-cell carcinoma. $N$ Engl J Med 2007; 356:115-24.

4. Motzer RJ, McCann L, Deen K. Pazopanib versus sunitinib in renal cancer. N Engl J Med 2013; 369:1968-70.

5. Motzer RJ, Michaelson MD, Redman BG, et al. Activity of SU11248, a multitargeted inhibitor of vascular endothelial growth factor receptor and plateletderived growth factor receptor, in patients with metastatic renal cell carcinoma. J Clin Oncol 2006; 24:16-24.

6. Motzer RJ, Rini BI, Bukowski RM, et al. Sunitinib in patients with metastatic renal cell carcinoma. JAMA 2006; 295:2516-24.

7. Escudier B, Porta C, Schmidinger M, et al. Renal cell carcinoma: ESMO Clinical Practice Guidelines for diagnosis, treatment and follow-up. Ann Oncol 2016; 27: v58-68.

8. Barrios CH, Hernandez-Barajas D, Brown MP, et al. Phase II trial of continuous once-daily dosing of sunitinib as first-line treatment in patients with metastatic renal cell carcinoma. Cancer 2012; 118:1252-9.

9. Motzer RJ, Hutson TE, Olsen MR, et al. Randomized phase II trial of sunitinib on an intermittent versus continuous dosing schedule as first-line therapy for advanced renal cell carcinoma. I Clin Oncol 2012; 30:1371-7.

10. Gore ME, Szczylik C, Porta C, et al. Safety and efficacy of sunitinib for metastatic renal-cell carcinoma: an expanded-access trial. Lancet Oncol 2009; 10: 757-63. 
11. Gore ME, Szczylik C, Porta C, et al. Final results from the large sunitinib global expanded-access trial in metastatic renal cell carcinoma. $\mathrm{Br} J$ Cancer 2015; 113:12-9.

12. Motzer RJ, Hutson TE, Cella D, et al. Pazopanib versus sunitinib in metastatic renal-cell carcinoma. N Engl J Med 2013; 369:722-31.

13. Escudier B, Pluzanska A, Koralewski P, et al. Bevacizumab plus interferon alfa-2a for treatment of metastatic renal cell carcinoma: a randomised, double-blind phase III trial. Lancet 2007; 370:2103-11.

14. Sternberg CN, Davis ID, Mardiak J, et al. Pazopanib in locally advanced or metastatic renal cell carcinoma: results of a randomized phase III trial. J Clin Oncol $2010 ; 28: 1061-8$.

15. Hutson TE, Escudier B, Esteban E, et al. Randomized phase III trial of temsirolimus versus sorafenib as second-line therapy after sunitinib in patients with metastatic renal cell carcinoma. J Clin Oncol 2014; 32:760-7.

16. Motzer RJ, Escudier B, Oudard S, et al. Efficacy of everolimus in advanced renal cell carcinoma: a double-blind, randomised, placebo-controlled phase III trial. Lancet 2008; 372:449-56.

17. Porta C, Procopio G, Carteni G, et al. Sequential use of sorafenib and sunitinib in advanced renal-cell carcinoma (RCC): an Italian multicentre retrospective analysis of 189 patient cases. BJU Int 2011; 108:E250-7.

18. Rini BI, Escudier B, Tomczak P, et al. Comparative effectiveness of axitinib versus sorafenib in advanced renal cell carcinoma (AXIS): a randomised phase 3 trial Lancet 2011; 378:1931-9.

19. Molina AM, Jia X, Feldman DR, et al. Long-term response to sunitinib therapy for metastatic renal cell carcinoma. Clin Genitourin Cancer 2013; 11 297-302.

20. Rini BI, Michaelson MD, Rosenberg JE, et al. Antitumor activity and biomarker analysis of sunitinib in patients with bevacizumab-refractory metastatic renal cell carcinoma. J Clin Oncol 2008; 26:3743-8.

21. Tomita Y, Shinohara N, Yuasa T, et al. Overall survival and updated results from a phase II study of sunitinib in Japanese patients with metastatic renal cell carcinoma. Jpn J Clin Oncol 2010; 40:1166-72.

22. Uemura H, Shinohara N, Yuasa T, et al. A phase II study of sunitinib in Japanese patients with metastatic renal cell carcinoma: insights into the treatment, efficacy and safety. Ipn I Clin Oncol 2010; 40:194-202.

23. Escudier B, Roigas J, Gillessen S, et al. Phase II study of sunitinib administered in continuous once-daily dosing regimen in patients with cytokine-refractory metastatic renal cell carcinoma. I Clin Oncol 2009; 27:4068-75.

24. Grünwald V, Lin X, Kalanovic D, Simantov R. Early tumour shrinkage: a tool for the detection of early clinical activity in metastatic renal cell carcinoma. Eur Urol 2016; 70:1006-15
25. Templeton AJ, Knox JJ, Lin X, et al. Change in neutrophil-to-lymphocyte ratio in response to targeted therapy for metastatic renal cell carcinoma as a prognosticator and biomarker of efficacy. Eur Urol 2016; 70:358-64.

26. Molina AM, Lin X, Korytowsky B, et al. Sunitinib objective response in metastatic renal cell carcinoma: analysis of 1059 patients treated on clinical trials. Eur J Cancer 2014; 50:351-8.

27. Porta C, Gore ME, Rini BI, et al. Long-term safety of sunitinib in metastatic renal cell carcinoma. Eur Urol 2016; 69:345-51.

28. Donskov F, Michaelson MD, Puzanov I, et al. Sunitinib-associated hypertension and neutropenia as efficacy biomarkers in metastatic renal cell carcinoma patients. Br J Cancer 2015; 113:1571-80.

29. Rini BI, Cohen DP, Lu DR, et al. Hypertension as a biomarker of efficacy in patients with metastatic renal cell carcinoma treated with sunitinib. I Natl Cancer Inst 2011; 103:763-73.

30. Krajewski KM, Franchetti Y, Nishino M, et al. 10\% Tumor diameter shrinkage on the first follow-up computed tomography predicts clinical outcome in patients with advanced renal cell carcinoma treated with angiogenesis inhibitors: a followup validation study. Oncologist 2014; 19:507-14.

31. Abel EJ, Culp SH, Tannir NM, Tamboli P, Matin SF, Wood CG. Early primary tumor size reduction is an independent predictor of improved overall survival in metastatic renal cell carcinoma patients treated with sunitinib. Eur Urol 2011; 60 1273-9.

32. Grünwald V, McKay RR, Krajewski KM, et al. Depth of remission is a prognostic factor for survival in patients with metastatic renal cell carcinoma. Eur Urol 2015; 67:952-8.

33. Ohno Y, Nakashima J, Ohori M, Hatano T, Tachibana M. Pretreatment neutrophil-to-lymphocyte ratio as an independent predictor of recurrence in patients with nonmetastatic renal cell carcinoma. J Urol 2010; 184:873-8.

34. Pichler M, Hutterer GC, Stoeckigt C, et al. Validation of the pre-treatment neutrophil-lymphocyte ratio as a prognostic factor in a large European cohort of renal cell carcinoma patients. Br J Cancer 2013; 108:901-7.

35. Motzer RJ, Escudier B, Bukowski R, et al. Prognostic factors for survival in 1059 patients treated with sunitinib for metastatic renal cell carcinoma. $\mathrm{Br} J$ Cancer 2013; 108:2470-7

36. Heng DY, Xie W, Regan MM, et al. Prognostic factors for overall survival in patients with metastatic renal cell carcinoma treated with vascular endothelia growth factor-targeted agents: results from a large, multicenter study. J Clin Oncol 2009; 27:5794-9.

37. Motzer RJ, Bacik J, Murphy BA, Russo P, Mazumdar M. Interferon-alfa as a comparative treatment for clinical trials of new therapies against advanced renal cell carcinoma. J Clin Oncol 2002; 20:289-96. 


\section{Long-term Response to Sunitinib Treatment}

Supplemental Table 1 Clinical Studies Included in the Analysis

\begin{tabular}{l|c|c|c}
\hline ClinicalTrials.gov ID & Treatment Setting & Dosing & Publication \\
NCT00054886 & Cytokine-refractory mRCC (phase II) & $50 \mathrm{mg} / \mathrm{d}$, Schedule $4 / 2$ & 5 \\
\hline NCT00077974 & Cytokine-refractory mRCC (phase II) & $50 \mathrm{mg} / \mathrm{d}$, Schedule $4 / 2$ & 5 \\
NCT00083889 & Treatment-naïv mRCC (Pivotal phase III trial) & $50 \mathrm{mg} / \mathrm{d}$ Schedule $4 / 2$ & 5 \\
NCT00130897 & Treatment-naïve and cytokine-refractory mRCC (EAP) & $50 \mathrm{mg} / \mathrm{d}$, Schedule $4 / 2$ & 10,11 \\
NCT00089648 & Bevacizumab-refractory mRCC (phase II) & $50 \mathrm{mg} / \mathrm{d}$, Schedule $4 / 2$ & 20 \\
\hline NCT00137423 & Cytokine-refractory mRCC (phase II) & $37.5 \mathrm{mg} / \mathrm{d}$, CDD (morning or evening) & 23 \\
NCT00267748 & Treatment-naïve mRCC (Renal EFFECT, phase II) & $50 \mathrm{mg} / \mathrm{d}$, Schedule $4 / 2$ or 37.5 CDD & 9 \\
\hline NCT00254540 & Treatment-naïve and cytokine-refractory mRCC (phase II) & $50 \mathrm{mg} / \mathrm{d}$, Schedule $4 / 2$ & 21,22 \\
\hline NCT00338884 & Treatment-naïve mRCC (phase II) & $37.5 \mathrm{mg} / \mathrm{d}$ CDD & 8 \\
\hline
\end{tabular}

Abbreviations: $\mathrm{CDD}=$ continuous once-daily dosing; EAP = Expanded Access Program; ID = identifier; $\mathrm{mRCC}=$ metastatic renal cell carcinoma; Schedule $4 / 2=4$ weeks on treatment followed by 2 weeks off treatment. 
Nizar M. Tannir et al

Supplemental Table 2 Patient Demographics and Baseline Characteristics

\begin{tabular}{|c|c|c|c|}
\hline Characteristics & $\begin{array}{c}\text { LTRs } \\
\mathbf{n}=\mathbf{8 9 8}\end{array}$ & $\begin{array}{c}\text { Others } \\
n=4816\end{array}$ & $\begin{array}{c}\text { All Patients } \\
\mathrm{n}=\mathbf{5 7 1 4}\end{array}$ \\
\hline \multicolumn{4}{|l|}{ Patient Demographics } \\
\hline \multicolumn{4}{|l|}{ Age, y } \\
\hline Median (range) & $60(23-89)$ & 59 (19-88) & $60(19-89)$ \\
\hline$<65$ & $602(67.0)$ & $3214(66.7)$ & 3816 (66.8) \\
\hline$\geq 65$ & $296(33.0)$ & $1602(33.3)$ & $1898(33.2)$ \\
\hline \multicolumn{4}{|l|}{ Sex } \\
\hline Male & $672(74.8)$ & 3501 (72.7) & $4173(73.0)$ \\
\hline Female & $226(25.2)$ & $1315(27.3)$ & $1541(27.0)$ \\
\hline \multicolumn{4}{|l|}{ Race } \\
\hline White & 751 (83.6) & $3862(80.2)$ & $4613(80.7)$ \\
\hline Black & $3(0.3)$ & $49(1.0)$ & $52(0.9)$ \\
\hline Asian & $60(6.7)$ & $410(8.5)$ & $470(8.2)$ \\
\hline Other & $77(8.6)$ & $408(8.5)$ & $485(8.5)$ \\
\hline \multicolumn{4}{|l|}{ Region } \\
\hline United States & $162(18.0)$ & 896 (18.6) & $1058(18.5)$ \\
\hline Non-United States & $734(81.7)$ & 3914 (81.3) & $4648(81.3)$ \\
\hline Missing & $2(0.2)$ & $6(0.1)$ & $8(0.1)$ \\
\hline \multicolumn{4}{|l|}{ Disease characteristics } \\
\hline \multicolumn{4}{|c|}{ ECOG PS } \\
\hline 0 & $544(60.6)$ & $2030(42.2)$ & $2574(45.0)$ \\
\hline 1 & $303(33.7)$ & $2091(43.4)$ & $2394(41.9)$ \\
\hline$\geq 2$ & $36(4.0)$ & $603(12.5)$ & 639 (11.2) \\
\hline Missing & $15(1.7)$ & $92(1.9)$ & $107(1.9)$ \\
\hline \multicolumn{4}{|c|}{$\begin{array}{l}\text { Time from diagnosis to } \\
\text { treatment, } y\end{array}$} \\
\hline$<1$ & $242(26.9)$ & $1841(38.2)$ & $2083(36.5)$ \\
\hline$\geq 1$ & $653(72.7)$ & $2907(60.4)$ & $3560(62.3)$ \\
\hline Missing & $3(0.3)$ & $68(1.4)$ & $71(1.2)$ \\
\hline \multicolumn{4}{|l|}{ Prior nephrectomy } \\
\hline Yes & $834(92.9)$ & $4242(88.1)$ & $5076(88.8)$ \\
\hline No & $64(7.1)$ & $574(11.9)$ & 638 (11.2) \\
\hline \multicolumn{4}{|l|}{ Site of metastases } \\
\hline Bone & $231(25.7)$ & $1622(33.7)$ & $1853(32.4)$ \\
\hline Lung & $663(73.8)$ & 3666 (76.1) & $4329(75.8)$ \\
\hline Liver & $186(20.7)$ & 1318 (27.4) & 1504 (26.3) \\
\hline Brain & $24(2.7)$ & $316(6.6)$ & $340(6.0)$ \\
\hline Other & $489(54.5)$ & 2665 (55.3) & 3154 (55.2) \\
\hline \multicolumn{4}{|c|}{ No. of metastatic sites ${ }^{a}$} \\
\hline 1 & 36 (21.95) & $182(18.07)$ & 218 (18.62) \\
\hline 2 & $56(34.15)$ & $292(29.00)$ & $348(29.72)$ \\
\hline 3 & $41(25.00)$ & $255(25.32)$ & $296(25.28)$ \\
\hline$>3$ & 31 (18.90) & $211(20.95)$ & $242(20.67)$ \\
\hline Missing & 0 & $67(6.65)$ & $67(5.72)$ \\
\hline \multicolumn{4}{|l|}{ MSKCC risk groups } \\
\hline Low $(0)$ & $80(48.78)$ & $287(28.50)$ & 367 (31.34) \\
\hline Intermediate (1-2) & 79 (48.17) & $578(57.40)$ & $657(56.11)$ \\
\hline Poor $(\geq 3)$ & $4(2.44)$ & $126(12.51)$ & $130(11.10)$ \\
\hline Missing & $1(0.61)$ & $16(1.59)$ & $17(1.45)$ \\
\hline
\end{tabular}

Supplemental Table 2 Continued

\begin{tabular}{|c|c|c|c|}
\hline Characteristics & $\begin{array}{c}\text { LTRs } \\
\mathbf{n}=898\end{array}$ & $\begin{array}{c}\text { Others } \\
\mathrm{n}=\mathbf{4 8 1 6}\end{array}$ & $\begin{array}{c}\text { All Patients } \\
\mathrm{n}=\mathbf{5 7 1 4}\end{array}$ \\
\hline \multicolumn{4}{|c|}{ Laboratory assessments } \\
\hline \multicolumn{4}{|c|}{ Hemoglobin } \\
\hline$>\operatorname{LLN}$ & $551(61.4)$ & 1935 (40.2) & $2486(43.5)$ \\
\hline$\leq \mathrm{LLN}$ & $336(37.4)$ & $2803(58.2)$ & $3139(54.9)$ \\
\hline Missing & $11(1.2)$ & $78(1.6)$ & $89(1.6)$ \\
\hline \multicolumn{4}{|c|}{ Corrected calcium, mg/dL } \\
\hline$>10$ & $93(10.4)$ & $1030(21.4)$ & $1123(19.7)$ \\
\hline$\leq 10$ & $710(79.1)$ & $3257(67.6)$ & $3967(69.4)$ \\
\hline Missing & $95(10.6)$ & $529(11.0)$ & $624(10.9)$ \\
\hline \multicolumn{4}{|l|}{$\mathrm{LDH}$} \\
\hline$>1.5$ ULN & $48(5.3)$ & $579(12.0)$ & $627(11.0)$ \\
\hline$\leq 1.5$ ULN & $757(84.3)$ & $3662(76.0)$ & $4419(77.3)$ \\
\hline Missing & $93(10.4)$ & $575(11.9)$ & $668(11.7)$ \\
\hline \multicolumn{4}{|l|}{ Platelets } \\
\hline$>U L N$ & $76(8.5)$ & $1032(21.4)$ & $1108(19.4)$ \\
\hline$\leq \mathrm{ULN}$ & $811(90.3)$ & $3700(76.8)$ & $4511(78.9)$ \\
\hline Missing & $11(1.2)$ & $84(1.7)$ & $95(1.7)$ \\
\hline \multicolumn{4}{|c|}{ Body mass index, $\mathrm{kg} / \mathrm{m}^{2}$} \\
\hline$\geq 25$ & $580(64.6)$ & $2510(52.1)$ & $3090(54.1)$ \\
\hline $18.5-25$ & $248(27.6)$ & $1804(37.5)$ & $2052(35.9)$ \\
\hline$<18.5$ & $9(1.0)$ & $164(3.4)$ & $173(3.0)$ \\
\hline Missing & $61(6.8)$ & $338(7.0)$ & $399(7.0)$ \\
\hline \multicolumn{4}{|l|}{ NLR } \\
\hline$\leq 3$ & $559(62.2)$ & $1988(41.3)$ & $2547(44.6)$ \\
\hline$>3$ & $316(35.2)$ & 2659 (55.2) & $2975(52.1)$ \\
\hline Missing & $23(2.6)$ & 169 (3.5) & $192(3.4)$ \\
\hline
\end{tabular}

NOTE. Values are $n(\%)$ unless otherwise stated.

Abbreviations: ECOG PS = Eastern Cooperative Oncology Group performance status; $\mathrm{LDH}=$ lactate dehydrogenase; LLN = lower limit of normal; LTR = long-term responder; MSKCC = Memorial Sloan Kettering Cancer Center; NLR = neutrophil-to-lymphocyte ratio; $\mathrm{ULN}=$ upper limit of normal.

${ }^{\text {a}}$ For some studies the actual sites were not mapped to the integrated database and could not be reported. 


\section{Long-term Response to Sunitinib Treatment}

Supplemental Table 3 Cox Proportional Analysis of Overall Survival for LTRs Versus Others

\begin{tabular}{|c|c|c|c|}
\hline \multirow[b]{2}{*}{ Parameter } & \multicolumn{3}{|c|}{ Overall Survival } \\
\hline & Hazard Ratio & $95 \% \mathrm{CI}$ & $\boldsymbol{P}$ \\
\hline Age (<65 vs. $\geq 65$ y) & 0.86 & 0.79-0.95 & .0018 \\
\hline Sex (female vs. male) & 0.98 & $0.89-1.08$ & .6824 \\
\hline \multicolumn{4}{|l|}{ Race } \\
\hline Asian vs. white & 1.02 & $0.89-1.18$ & .7495 \\
\hline Black vs. white & 1.22 & 0.77-1.95 & .3998 \\
\hline Not applicable vs. white & 0.98 & $0.73-1.31$ & .8800 \\
\hline Other vs. white & 1.10 & $0.94-1.28$ & .2480 \\
\hline \multicolumn{4}{|l|}{ ECOG PS } \\
\hline 0 vs. $1-2$ & 0.66 & $0.60-0.72$ & $<.0001$ \\
\hline$>2$ vs. $1-2$ & 2.55 & 1.93-3.37 & $<.0001$ \\
\hline Time from diagnosis to treatment ( $\geq 1 \mathrm{vs.}<1 \mathrm{y}$ ) & 0.74 & $0.67-0.82$ & $<.0001$ \\
\hline Clear cell histology (no vs. yes) & 1.41 & $1.25-1.61$ & $<.0001$ \\
\hline \multicolumn{4}{|l|}{ Metastasis (no vs. yes) } \\
\hline Liver & 0.89 & $0.81-0.97$ & .0114 \\
\hline Lung & 0.72 & $0.65-0.80$ & $<.0001$ \\
\hline Bone & 0.84 & $0.76-0.91$ & $<.0001$ \\
\hline Other site & 0.84 & $0.76-0.91$ & $<.0001$ \\
\hline LDH (>1.5 vs. $\leq 1.5$ ULN) & 1.61 & $1.43-1.81$ & $<.0001$ \\
\hline Corrected calcium (>10 vs. $\leq 10 \mathrm{mg} / \mathrm{dL}$ ) & 1.31 & $1.19-1.45$ & $<.0001$ \\
\hline Hemoglobin (>LLN vs. <LLN) & 0.72 & $0.65-0.80$ & $<.0001$ \\
\hline Platelets ( $\leq$ ULN vs. >ULN) & 0.75 & $0.67-0.83$ & $<.0001$ \\
\hline Prior nephrectomy (no vs. yes) & 1.10 & $0.96-1.25$ & .1642 \\
\hline Prior therapy (no vs. yes) & 0.94 & $0.85-1.04$ & .2317 \\
\hline BMI $\left(<25 \mathrm{~kg} / \mathrm{m}^{2}\right.$ vs. $\left.>25 \mathrm{~kg} / \mathrm{m}^{2}\right)$ & 1.17 & $1.07-1.27$ & .0008 \\
\hline $\mathrm{NLR}(\leq 3$ vs. $>3)$ & 0.62 & $0.56-0.68$ & $<.0001$ \\
\hline
\end{tabular}

Abbreviations: $\mathrm{BMI}=$ body mass index; $\mathrm{Cl}=$ confidence interval; $\mathrm{ECOG} \mathrm{PS}=$ Eastern Cooperative Oncology Group performance status; $\mathrm{LDH}=$ lactate dehydrogenase; $\mathrm{LLN}=$ lower limit of normal; LTR = long-term responder; NLR = neutrophil-to-lymphocyte ratio; ULN = upper limit of normal. 
Supplemental Table 4 Change in Neutrophil-to-Lymphocyte Ratio (NLR) From Baseline to Week 6, Low (NLR $\leq 3$ ) Versus High $(\mathrm{NLR}>3)$

\begin{tabular}{|c|c|c|c|c|c|c|c|c|}
\hline & \multicolumn{4}{|c|}{ LTRs } & \multicolumn{4}{|c|}{ Others } \\
\hline & $\begin{array}{c}\text { High to Low } \\
\mathrm{n}=196\end{array}$ & $\begin{array}{l}\text { High to High } \\
\mathrm{n}=120\end{array}$ & $\begin{array}{c}\text { Low to Low } \\
n=502\end{array}$ & $\begin{array}{c}\text { Low to High } \\
\mathrm{n}=57\end{array}$ & $\begin{array}{c}\text { High to Low } \\
\mathrm{n}=1057\end{array}$ & $\begin{array}{c}\text { High to High } \\
\mathrm{n}=990\end{array}$ & $\begin{array}{c}\text { Low to Low } \\
n=1528\end{array}$ & $\begin{array}{c}\text { Low to High } \\
n=266\end{array}$ \\
\hline \multicolumn{9}{|l|}{ Overall survival } \\
\hline Median, mo & NR & 67.52 & $N R$ & 57.79 & 16.55 & 10.29 & 23.57 & 15.00 \\
\hline Hazard ratio & & $0.730^{\mathrm{a}}$ & & $0.439^{b}$ & & $0.612^{\mathrm{a}}$ & & $0.490^{b}$ \\
\hline$P$ & & $.2204^{\mathrm{a}}$ & & $.0035^{b}$ & & $<.0001^{\mathrm{a}}$ & & $<.0001^{b}$ \\
\hline Hazard ratio 95\% Cl & & $0.4417-1.2074$ & & $0.2529-0.7624$ & & $0.5505-0.68$ & & $0.4173-0.5762$ \\
\hline \multicolumn{9}{|l|}{ Progression-free survival } \\
\hline Median, mo & 32.04 & 27.60 & 33.36 & 25.06 & 7.98 & 5.87 & 9.76 & 7.55 \\
\hline Hazard ratio & & $0.864^{\mathrm{a}}$ & & $0.545^{b}$ & & $0.755^{\mathrm{a}}$ & & $0.692^{b}$ \\
\hline$P$ & & $.3229^{\mathrm{a}}$ & & $.0002^{b}$ & & $<.0001^{\mathrm{a}}$ & & $<.0001^{b}$ \\
\hline Hazard ratio 95\% Cl & & $0.6473-1.154$ & & $0.3963-0.7501$ & & $0.6811-0.8367$ & & $0.5938-0.807$ \\
\hline \multicolumn{9}{|l|}{ Objective response rate } \\
\hline n (\%) & $112(57.14)$ & 47 (39.16) & 269 (53.58) & $18(31.57)$ & 168 (15.89) & $96(9.70)$ & 346 (22.64) & $39(14.66)$ \\
\hline$P$ & & $.0021^{\mathrm{a}}$ & & $.0021^{\mathrm{b}}$ & & $<.0001^{\mathrm{a}}$ & & $.0037^{\mathrm{b}}$ \\
\hline Odds ratio & & $2.0709^{\mathrm{a}}$ & & $2.5009^{b}$ & & $1.7598^{\mathrm{a}}$ & & $1.7038^{\mathrm{b}}$ \\
\hline Odds ratio 95\% Cl & & $1.3034-3.2904$ & & $1.3927-4.4907$ & & $1.3469-2.2993$ & & $1.1884-2.4427$ \\
\hline
\end{tabular}

Abbreviations: $\mathrm{Cl}=$ confidence interval; $\mathrm{LTR}=$ long-term responder; $\mathrm{NR}=$ not reached.

aHigh to low versus high to high.

bow to low versus low to high. 